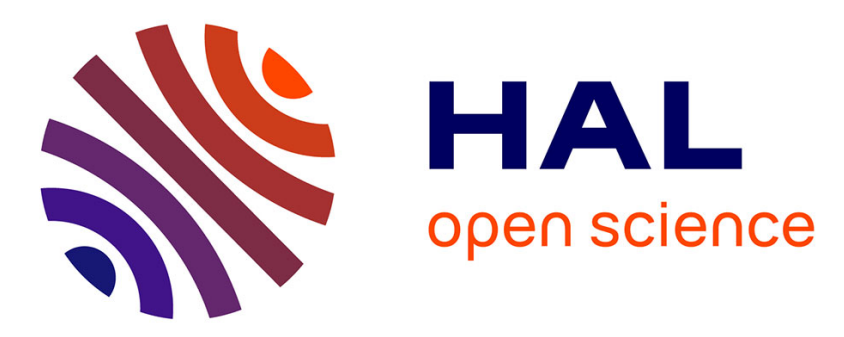

\title{
Can the gut be the missing piece in uncovering PD pathogenesis?
}

\author{
Guillaume Chapelet, Laurène Leclair-Visonneau, Thomas Clairembault, \\ Michel Neunlist, Pascal Derkinderen
}

\section{To cite this version:}

Guillaume Chapelet, Laurène Leclair-Visonneau, Thomas Clairembault, Michel Neunlist, Pascal Derkinderen. Can the gut be the missing piece in uncovering PD pathogenesis?. Parkinsonism \& Related Disorders, 2019, 59, pp.26 - 31. 10.1016/j.parkreldis.2018.11.014 . hal-03486438

\section{HAL Id: hal-03486438 https://hal.science/hal-03486438}

Submitted on 20 Dec 2021

HAL is a multi-disciplinary open access archive for the deposit and dissemination of scientific research documents, whether they are published or not. The documents may come from teaching and research institutions in France or abroad, or from public or private research centers.
L'archive ouverte pluridisciplinaire HAL, est destinée au dépôt et à la diffusion de documents scientifiques de niveau recherche, publiés ou non, émanant des établissements d'enseignement et de recherche français ou étrangers, des laboratoires publics ou privés.

\section{다)(1) $(5$}

Distributed under a Creative Commons Attribution - NonCommerciall 4.0 International 


\section{Can the gut be the missing piece in uncovering PD pathogenesis?}

Guillaume Chapelet, MD ${ }^{1,2,3}$, Laurène Leclair-Visonneau, MD, $\mathrm{PhD}^{1,2,3,4}$, Thomas

Clairembault, $\mathrm{PhD}^{1,2}$, Michel Neunlist, $\mathrm{PhD}^{1,2}$ and Pascal Derkinderen MD, $\mathrm{PhD}^{1,2,3,5}$

${ }^{1}$ Inserm, U1235, Faculté de Médecine, 1 rue Gaston Veil, F-44035 Nantes, France

2University Nantes, Faculté de Médecine, 1 rue Gaston Veil, F-44035 Nantes, France

${ }^{3}$ CHU Nantes, Clinical Gerontology Department, Bd Jacques Monod, F-44093 Nantes, France

${ }^{4}$ CHU Nantes, Department of Clinical Neurophysiology, Bd Jacques Monod, F-44093

Nantes, France

${ }^{8}$ CHU Nantes, Department of Neurology, Nantes, Bd Jacques Monod, F-44093 Nantes, France

Corresponding author: Pascal Derkinderen, Inserm U1235 Nantes, 1 rue Gaston Veil, 44035 Nantes, France. Tel: +33(0)240165202, Fax: +33(0)240165203, E-mail:

pascal.derkinderen@chu-nantes.fr; derkinderenp@yahoo.fr.

Keywords: Parkinson's disease; gut-brain axis; enteric nervous system; gut microbiota; inflammation; intestinal epithelial barrier. 


\begin{abstract}
It is now well established that Parkinson's disease (PD) is not only a movement disorder of the CNS but also a gastrointestinal disorder affecting the enteric nervous system (ENS). The gut-brain axis is a bidirectional communication between the brain and the gastrointestinal tract, which comprises besides the CNS and the ENS, the intestinal epithelial barrier, the intestinal microbiota and the enteroendocrine systems. In this review, we present the clinical and pathological evidence suggesting that the gut-brain axis is dysfunctional in PD by discussing the possible role of gut microbiota, inflammation and permeability in the development of the disease.
\end{abstract}

\title{
Funding sources
}

This research did not receive any specific grant from funding agencies in the public, commercial, or not-for-profit sectors. 
An accumulating body of literature has emerged in the past 25 years to show that PD is not only disorder of the brain but also of the gastrointestinal (GI) tract and more generally of the gut-brain axis. GI symptoms occur in almost every PD patient at some point [1] and autopsy studies have consistently shown that alpha-synuclein aggregates are found in the myenteric plexus of the enteric nervous system (ENS) in nearly every case examined pathologically [2-4]. Based on the topographic distribution of alphasynuclein deposits established after autopsy, Braak and coworkers hypothesized that PD pathology may start in the GI tract then spread to the brain via the vagus nerve $[5,6]$. The arguments for or against this so-called Braak's hypothesis have been thoroughly reviewed in two recent articles [7,8] and therefore the possible role of the vagus nerve in PD pathogenesis will not be discussed in the current review. We will instead focus on the role of other components of the gut-brain axis, including gut microbiota, epithelial intestinal barrier and enteroendocrine systems in the development of PD. We will first provide an overview of the different components of the gut-brain axis then discuss the possible evidence that changes in the composition of gut microbiota, gastrointestinal inflammation, intestinal barrier dysfunction and enteroendocrine cells are implicated in PD pathogenesis.

\section{What is the gut-brain axis made of?}

The notion of a gut-brain axis, a bidirectional communication system involving neural and humoral mechanisms, was initially proposed by Sudo and colleagues in 2004 who discovered the impaired stress response in germ-free mice [9]. This gut-brain axis consists of "hard-wired" anatomical neural connections, humoral components provided by the endocrine and immune systems and the intestinal epithelium and the gut microbiota (Figure 1).

- The neural connections between the gut and brain include the central nervous system (CNS), both brain and spinal cord, the autonomic nervous system, the enteric nervous system (ENS) and the hypothalamic pituitary adrenal axis. The autonomic system, with the sympathetic and parasympathetic pathways, drives both afferent signals, arising from the lumen and transmitted though enteric, spinal and vagal pathways to the CNS, and efferent signals from the CNS to the ENS and intestinal wall [10]. The vagus nerve, which innervates the entire digestive tract until the left colonic flexure is able to sense microbiota 
metabolites and to transfer this information to the brain [10] . The hypothalamic pituitary adrenal axis is part of the limbic system and considered the core stress efferent axis that coordinates the adaptive responses of the organism to stressors of any kind [11]. The ENS is an integrative neuronal network organized in two ganglionated plexuses, myenteric and submucosal, composed of neurons and enteric glial cells (EGC) [12]. It is suggested that EGC represent the ENS counterpart of CNS astrocytes since they resemble astrocytes both morphologically and immunohistochemically [13] (Figure 1).

- The humoral components of the gut-brain axis consist the enteroendocrine system, the mucosal immune system and the microbiota metabolites. Enteroendocrine cells produce hormones such as cholecystokinin and ghrelin, both of which regulate appetite, and 5-hydroxytryptamine, which has a broad range of effects on gut and brain functions [14] (Figure 1).

- The intestinal epithelium forms a regulated barrier, known as intestinal epithelial barrier (IEB), between the blood circulation and the contents of the intestinal lumen. It prevents the passage of noxious contents while allowing the absorption and secretion of nutrients [15]. Among the most important structures of the intestinal barrier are the epithelial tight junctions (TJs) that connect adjacent enterocytes together to determine paracellular permeability through the lateral intercellular space [16] (Figure 2A). They are formed by transmembrane proteins such as claudins and occludins connected to the actin cytoskeleton via high molecular weight proteins called zona occludens (ZO-1, ZO-2 and 3) [16] (Figure 2A). The gut microbiota consists of more than one trillion of microorganisms, including mainly bacteria, which interact directly with the intestinal epithelium and contribute to maintain the integrity of the IEB, through the regulation of TJs proteins expression [17]. In addition, gut microbiota and its metabolites might also influence blood brain barrier integrity and permeability along with microglia function and maturation in the CNS $[18,19]$.

\section{Gut microbiota in PD}

The GI involvement in PD led several groups to analyze the composition of gut microbiota in PD and so far, 11 studies have been published (Table 1) [20-30]. Despite 
differences in terms of patient recruitment (number and selection criteria) and methods of analysis (molecular biology, bioinformatics and statistics), all these studies identified changes in the composition of the gut microbiota in PD (Table 1). Compared to the control population, an increase of Akkermansia (6 studies) [20-25] and Lactobacillus bacteria (5 studies) [20,25-28] as well as a decrease of Prevotella bacteria (6 studies) $[20,22-24,26,27]$ was observed in PD patients. The other concordant results between the studies were the lower abundance of Faecalibacterium (4 studies) [22,24,27,29] and Blautia (3 studies) [21,24,29] and an increase in the number of Bifidobacterium (3 studies) $[22,24,27]$. It is unlikely that these changes were the sole consequence of PD treatment as they were also observed in early disease stage L-DOPA-naïve PD patients $[23,25]$. To further investigate a possible role for gut microbiota in PD, Sampson et al. used a transgenic PD mouse model, which overexpress high levels of human alphasynuclein in their brains and develop progressive motor deficits. The authors raised these mice in a germ-free environment or conventionally. Germ-free and antibiotictreated animals had less motor dysfunction and less alpha-synuclein deposits in the brain than model mice with gut microbiota [31]. In addition, model mice that received fecal microbiota transplantation from PD patients had more motor symptoms compared with model animals that received fecal microbiota from healthy individuals. In a last set of experiments, the authors identified the short-chain fatty acid butyrate as one of the bacterial metabolite that might be involved in the deleterious effects of the microbiota of parkinsonian subjects [31]. It should be however noted that the effects of butyrate on PD pathology are not unequivocally established, since Unger et al. found a reduction of fecal butyrate in PD patients when compared to controls [22]. Using another approach with toxic rodent's models of PD, Choi et al. found that the number of Enterobacteriaceae, and more specifically Proteus mirabilis, was markedly increased in the feces of 1-méthyl-4phényl-1,2,3,6-tétrahydropyridine (MPTP) and 6-hydroxydopamine mouse models [32]. Quite remarkably, the repeated oral administration of Proteus mirabilis isolated from these two mouse models impaired motor function, induced dopaminergic neuronal loss in the substantia nigra, and promoted alpha-synuclein aggregation in both brain and colon of wild-type mice [32]. Additional experiments showed that lipopolysaccharide, a virulence factor of gram-negative bacteria may be, at least in part, responsible for the pathological changes induced by Proteus mirabilis. 


\section{Gut inflammation in PD}

Data from genetic studies support a close relationship between PD and the gut. Single nucleotide polymorphisms in the CARD15 gene known to be associated with Crohn's disease are over-represented in patients with $\mathrm{PD}$ [33] and, on the other hand, the Leucine-rich repeat kinase 2 (LRRK2) gene, which has emerged as the gene most commonly associated with both familial and sporadic PD, has been identified by genome-wide association studies as a major susceptibility gene for both $\mathrm{CD}$ and $\mathrm{PD}$ $[34,35]$. Two recent large retrospective cohort studies, by showing a higher incidence of subsequent PD among patients with IBD, tie even closer together PD and inflammatory bowel disorders [36,37]. In addition to IBD, two recent reports showed an association between irritable bowel syndrome and PD [38,39].

These findings logically led us to study the expression levels of the main proinflammatory cytokines (tumor necrosis factor- $\alpha$, interferon gamma, interleukin- 6 and interleukin-1 $\beta$ ) in the gut of PD patients [40]. By analyzing colonic biopsies from 19 PD patients and 14 age-matched healthy controls by real-time PCR, we found that the mRNA expression levels of all pro-inflammatory cytokines were significantly elevated in the ascending colon of PD patients compared to controls [40]. The amounts of proinflammatory cytokines were nevertheless markedly heterogenous between PD patients, as some showed levels similar to control subjects while others had a 4- to 6fold upregulation [40]. Subsequent correlation analyses showed that all proinflammatory cytokines were up-regulated within the same patients, thereby suggesting that only a subset of PD patients display an "enteric pro-inflammatory profile" [40]. Glial fibrillary acidic protein (GFAP), the canonical marker of EGC is known to be up regulated by pro-inflammatory cytokines such as interleukin-6 [41] and we therefore analyzed its expression levels in the same group of patients. Compared to controls, we found an increased expression of colonic GFAP in PD patients that was correlated with the mRNA expression levels of each pro-inflammatory cytokines [40]. These results, obtained with qPCR were confirmed at the protein level by Western blot [42]. Quite remarkably, similar changes were noted in experimental parkinsonism as the injection of 6hydroxydopamine into the medial forebrain bundle of rats was accompanied by an upregulation of tumor necrosis factor- $\alpha$, interleukin-1 $\beta$ and GFAP in the colon [43].

In addition to pro-inflammatory cytokines, we showed that the inducible enzyme cyclooxygenase-2 (COX-2) is also upregulated in the gastrointestinal tract in PD. COX-2, 
whose expression is increased in dopaminergic neurons of the substantia nigra in PD [44], catalyzes the first committed step in the synthesis of prostanoids, a large family of arachidonic acid metabolites that play a pivotal role in inflammation. Using colonic biopsies from 13 PD patients and 15 age-matched controls, we observed a significant 3.4- and 1.9- fold increase in the expression levels of COX-2 mRNA and protein in PD compared to controls, respectively [45].

More recently, Houser et al. used a multiplex immunoassay to conduct an extensive analysis of immune- and inflammatory-related proteins in the stool of 156 individuals with PD and 110 controls [46]. They found elevated levels of interleukin-1 $\alpha$, $1 \beta$ and C-reactive protein in the stool of PD patients. Although not significant, the levels of some upregulated factors tended to be inversely correlated with age and disease duration. Using a more focused approach, Schwiertz et al. found that calprotectin, a fecal marker of intestinal inflammation was also significantly increased in the feces of PD patients compared to controls [47].

Altogether, these studies provide converging evidence that classic inflammatory processes occur in the GI tract of PD patients in a way similar to the brain [48]. Moreover, they also suggest and that GI inflammation is more likely to occur in patients with a short disease duration. These findings are also in line with the observations obtained in the CNS showing that activated microglia, which drive the release of proinflammatory cytokines occur early in the disease process $[49,50]$.

\section{Gut permeability in PD}

Increased permeability of the IEB and changes in the expression levels of TJs proteins have been consistently reported in several digestive disorders such as inflammatory bowel disease and irritable bowel syndrome [51,52]. These observations, along with the existence of changes in gut microbiota composition and inflammation, suggest that PD patients may have a dysfunctional IEB and a 'leaky gut'. The urinary recovery ratio of orally ingested sugar probes, such as lactulose and mannitol, is frequently used to measure intestinal permeability in vivo [53]. To date, the three studies that evaluated intestinal permeability in PD with this approach have produced conflicting and divergent results. Two of these studies focused on the lactulose/mannitol ratio, which

evaluate small intestinal permeability. As a group, the 15 PD patients studied by Davies et al. had an increased urinary lactulose/mannitol excretion ratio compared to 
age and sex matched controls, but individual results in both groups were nevertheless highly overlapping [54]. Salat-Foix et al. showed that the lactulose/mannitol ratio was only marginally higher in 3 out of 12 PD patients [55]. In addition to lactulose/mannitol ratio, Forsyth et al. performed sucralose absorption for the evaluation of colon permeability in 9 PD patients and 10 controls [56]. They did not observe any difference in the urinary lactulose/mannitol excretion ratio between the two groups but found a higher permeability to sucralose in PD subjects [56].

The inconsistent results on intestinal permeability obtained with urinary excretion of sugar probes (table 2) prompted us to utilize another approach to measure IEB permeability in a larger sample size of PD subjects. Using Ussing chambers [34], we showed that there were no significant differences in para- and transcellular permeability between colonic biopsies from PD subjects and controls. Despite these negative results and in order to further investigate the IEB in PD, we analyzed the expression levels of the TJs proteins ZO-1 and, claudins and occludin by Western blot in colonic biopsies from PD subjects and healthy controls. A significant decrease in the expression of both occludin and claudins, but not of Z0-1 was observed in colonic samples of PD patients compared to controls [57]. These results obtained by Western blots were confirmed using immunohistochemistry experiments, which showed a marked disorganization of TJs in PD subjects compared to controls [57].

To summarize, because of their small sample size and divergent results, the existing studies on IEB in PD do not allow us to draw any definitive conclusions and it still remains to be determined if the IEB is dysfunctional in PD.

\section{Enteroendocrine cells and PD}

Enteroendocrine cells are chemosensory cells that are dispersed throughout the epithelium of the GI tract and oriented with their apical surface open to the lumen of the intestine, so that they can sense luminal contents [14]. Traditionally, enteroendocrine cells were viewed exclusively as hormone-producing cells of the GI tract, but a recent study showed that they also possess neuron-like properties and connect directly to both enteric neurons and EGC [58]. In addition, these cells express alpha-synuclein and they connect to alpha-synuclein expressing enteric neurons, leading to the assumption that enteroendocrine cells might be a link between the gut lumen and the enteric nerves to propagate pathological alpha-synuclein [59]. Although 
interesting, this scenario is nevertheless highly hypothetical and further studies in PD patients and animal models of PD are critically needed to support or to invalidate it.

\section{Conclusion and perspectives}

There has been an exponential growth research on gut-brain axis in PD over recent years and there is now a reasonable body of evidence suggesting that some of its main

components are dysfunctional in PD. Several independent studies have consistently reported changes in abundance of several bacterial genera as well as increased levels of inflammatory mediators in the PD gut. This, together with the observation showing that gut bacteria from PD patients worsen and accelerate motor impairment when transplanted into genetically susceptible transgenic mice, strongly suggest that changes in the composition of gut microbiome and gut inflammation are risk factors for PD. These findings although novel and interesting are nevertheless preliminary and there are still many unanswered questions. To cite only a few (i) what might be the link between the pro-inflammatory profile observed in the GI tract and the changes in microbiota composition? (ii) are the changes in gut microbiome primitive or secondary to the disease process itself or to disease complications such as constipation? (iii) why is the microbiota of some PD patients unable to promote motor deficits in transgenic mice? (iv) why is the GI inflammatory profile so heterogenous among PD patients? (v) are there any correlation between the microbiota or inflammatory profile with markers of disease severity, including dementia, autonomic dysfunction and RBD? as one might suggest that a more pronounced proinflammatory profile in the gut can be associated with a more severe disease phenotype. Studies in well-defined populations may help clarify this issue. Regarding intestinal permeability, we have seen that the small sample size and the heterogeneity of control population preclude drawing firm conclusions. In order to overcome the limitations of existing studies, future research should include a large number of subjects, with a pre-study calculation of the required sample size and the inclusions of patients spouses and relatives as controls, as such a strategy has proven to be useful to demonstrate intestinal hyperpermeability in Crohn's disease [52].

\section{Legends to figures}

Figure 1. Main components of the gut-brain axis. The gut-brain axis consists of 
bidirectional communication between the CNS and the ENS and comprised neural connections, humoral components provided by the endocrine system, microbiota and their products, and the intestinal epithelium. The neuronal network includes the ENS (enteric neurons and enteric glial cells, EGC), the sympathetic and parasympathetic pathways and the CNS. The enteroendocrine cells (EEC) mediate their action through the release of hormones such as 5-hydroxytryptamine (5-HT). Putative mechanisms by which gut bacteria modulate the brain include bacterial products that gain access to the brain via the bloodstream and the area postrema, such as short chain fatty acids (SCFA) and neurotransmitters (GABA, $\gamma$-aminobutyric acid). The microbial composition can shift from a resting state to a pro-inflammatory state in the presence of inflammatory mediators.

Figure 2. (A) Composition of tight junctions. Tight junctions (TJs) of epithelial intestinal cells form selective barriers that regulate paracellular permeability. They consist of proteins including occludin, claudins and Zonula occludens-1 (ZO-1). (B) Expression levels of claudin-1 are decreased in colonic biopsies from PD patients. Biopsies lysates were subjected to immunoblot analysis using antibodies against claudin-1. $\beta$-actin was used as a loading control. The optical densities of claudin-1 immunoreactive bands were measured, normalized to the optical densities of $\beta$-actin immunoreactive bands in the same samples and expressed as percentages of controls. Data correspond to mean \pm SEM of 11 samples for control subjects (C) and 31 samples for Parkinson's disease (PD) patients. Patients versus control, *: $\mathrm{p}<0.05$.

\section{Conflict of interest}

The authors declare that they have no conflict of interest.

\section{Author's contribution}

GC, LLV and PD wrote the first draft of the manuscript. MN and PD edited the final version. TC prepared the figures, performed and quantified the immunoblots. All authors approved the final version of the manuscript.

\section{Tables}




\begin{tabular}{|c|c|c|c|c|c|}
\hline Study & PD (n) & $C(n)$ & Technique & + & \\
\hline $\begin{array}{l}\text { Scheperjans } \\
\text { et al. } 2015 \\
{[20]}\end{array}$ & 72 & 72 & $16 \mathrm{~S}$ rRNA as & $\begin{array}{l}\text {-Lactobacillaceae (phylum } \\
\text { Firmicutes) } \\
\text {-Verrucomicrobiaceae } \\
\text { (phylum Verrucomicrobia), } \\
\text {-Bradyrhizobiaceae (phylum } \\
\text { Proteobacteria) } \\
\text {-Clostridiales Incertae Sedis } \\
\text { IV (phylum Firmicutes) }\end{array}$ & $\begin{array}{ll}\text { Prevotellaceae } & \text { (phylum } \\
\text { Bacteroidetes) } & \end{array}$ \\
\hline $\begin{array}{l}\text { Hasegawa et } \\
\text { al. } 2015 \text { [26] }\end{array}$ & 52 & 36 & qPCR & $\begin{array}{ll}\text {-Lactobacillus } & \text { (phylum } \\
\text { Firmicutes) } & \\
\text {-Enterococcacecae } & \text { (phylum } \\
\text { Firmicutes) } & \end{array}$ & 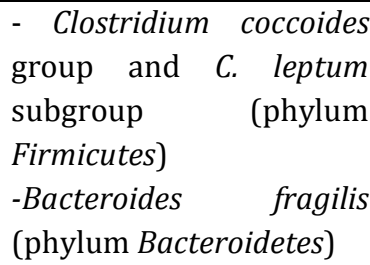 \\
\hline $\begin{array}{l}\text { Keshavarzian } \\
\text { et al., } 2015 \\
\text { [21] }\end{array}$ & 38 & 34 & $16 \mathrm{~S}$ rRNA as & $\begin{array}{l}\text {-Akkermansia (phylum } \\
\text { Verrucomicrobia) } \\
\text {-Oscillospira (phylum } \\
\text { Firmicutes) } \\
\text {-Bacteroides } \\
\text { (phylum Bacteroidetes) }\end{array}$ & $\begin{array}{l}\text {-Blautia, Coprococcus, } \\
\text { and Roseburia (phylum } \\
\text { Firmicutes) } \\
\text {-Faecalibacterium } \\
\text { prausnitzii (phylum } \\
\text { Firmicutes) } \\
\text {-Prevotellaceae (phylum } \\
\text { Bacteroidetes) }\end{array}$ \\
\hline $\begin{array}{l}\text { Unger et al. } \\
2016 \text { [22] }\end{array}$ & 34 & 34 & qPCR & $\begin{array}{l}\text {-Bifidobacterium (phylum } \\
\text { Actinobacteria) } \\
\text {-Enterobacteriaceae (phylum } \\
\text { Proteobacteria) }\end{array}$ & $\begin{array}{l}\text {-Prevotellaceae (phylum } \\
\text { Bacteroidetes) } \\
\text {-Faecalibacterium } \\
\text { prausnitzii (phylum } \\
\text { Firmicutes) } \\
\text {-Lactobacillaceae and } \\
\text { Enterococcaceae } \\
\text { (phylum Firmicutes) }\end{array}$ \\
\hline $\begin{array}{l}\text { Petrov et al. } \\
2017 \text { [27] }\end{array}$ & 89 & 66 & $16 \mathrm{~S}$ rRNA as & $\begin{array}{l}\text {-Christensenella, Catabacter, } \\
\text { Lactobacillus, Oscillospira } \\
\text { (phylum Firmicutes) } \\
\text {-Bifidobacterium (phylum } \\
\text { Actinobacteria) }\end{array}$ & $\begin{array}{l}\text {-Dorea, Faecalibacterium } \\
\text { (phylum Firmicutes) } \\
\text {-Bacteroides, Prevotella } \\
\text { (phylum Bacteroidetes) }\end{array}$ \\
\hline $\begin{array}{l}\text { Bedarf et al. } \\
2017 \text { [23] }\end{array}$ & 31 & 28 & $\begin{array}{l}\text { Shotgun } \\
\text { sequencing }\end{array}$ & $\begin{array}{ll}\text {-Akkermansia } & \text { (phylum } \\
\text { Verrucomicrobia) } & \\
\text {-phylum } & \text { Firmicutes } \\
\text { unclassified } & \\
\end{array}$ & $\begin{array}{l}\text {-Prevotellaceae (phylum } \\
\text { Bacteroidetes) } \\
\text {-Eubacterium (phylum } \\
\text { Erysipelotrichaceae) }\end{array}$ \\
\hline $\begin{array}{l}\text { Hill-Burns et } \\
\text { al. } 2017 \text { [24] }\end{array}$ & 212 & 136 & $16 \mathrm{~S}$ rRNA as & $\begin{array}{ll}\text {-Akkermansia } & \text { (phylum } \\
\text { Verrucomicrobia) } & \\
\text {-Lactobacillus } & \text { (phylum } \\
\text { Firmicutes) } & \\
\text {-Bifidobacteriaceae } & \text { (phylum } \\
\text { Bifidobacterium) } & \\
\end{array}$ & $\begin{array}{l}\text {-Lachnospiracea (phylum } \\
\text { Firmicutes) }\end{array}$ \\
\hline $\begin{array}{l}\text { Li et al } 2017 \\
\text { [29] }\end{array}$ & 24 & 14 & $16 \mathrm{~S}$ rRNA as & $\begin{array}{l}\text {-Escherichia-Shigella, Proteus } \\
\text { (phylum Proteobacteria) } \\
\text {-Streptococcus, Enterococcus } \\
\text { (phylum Firmicutes) }\end{array}$ & $\begin{array}{l}\text { Blautia, } \\
\text { Faecalibacterium, } \\
\text { Ruminococcus (phylum } \\
\text { Firmicutes) }\end{array}$ \\
\hline
\end{tabular}




\begin{tabular}{|c|c|c|c|c|c|}
\hline $\begin{array}{l}\text { Hopfner et al., } \\
2017 \text { [28] }\end{array}$ & 29 & 29 & $16 \mathrm{~S}$ rRNA as & $\begin{array}{ll}\text {-Lactobacillaceae, } & \\
\text { Enterococcaceae } & \text { (phylum } \\
\text { Firmicutes) } & \\
\text {-Barnesiellaceae } & \text { (phylum } \\
\text { Bacteroidetes) } & \end{array}$ & \\
\hline $\begin{array}{l}\text { Heintz- } \\
\text { Buschart et al. } \\
2018 \text { [25] }\end{array}$ & 76 & 78 & $\begin{array}{l}16 \mathrm{~S} \text { and } 18 \mathrm{~S} \\
\text { rRNA as }\end{array}$ & $\begin{array}{ll}\text { Akkermansia } & \text { (phylum } \\
\text { Verrucomicrobia) } & \end{array}$ & \\
\hline $\begin{array}{l}\text { Qian et al. } \\
2018[30]\end{array}$ & 45 & 45 & $16 \mathrm{~S}$ rRNA as & $\begin{array}{l}\text {-Clostridium IV, Holdemania, } \\
\text { Clostridium XVIII, } \\
\text { Butyricicoccus, Anaerotruncus } \\
\text { (phylum Firmicutes) } \\
\text {-Aquabacterium, } \\
\text { Sphingomonas (phylum } \\
\text { Proteobacteria) }\end{array}$ & $\begin{array}{l}\text { - Lactobacillus (phylum } \\
\text { Firmicutes) } \\
\text {-Sediminibacterium } \\
\text { (phylum Bacteroidetes) }\end{array}$ \\
\hline $\begin{array}{l}\text { Lin et al } \\
2018[60]\end{array}$ & 75 & 45 & $16 \mathrm{~S}$ rRNA as & $\begin{array}{l}\text {-Veillonellaceae (phylum } \\
\text { Firmicutes) } \\
\text {-phylum } \\
\text { Verrucomicrobiaceae } \\
\text { - phylum Bacteroidetes } \\
\text { Bifidobacteriaceae }\end{array}$ & $\begin{array}{l}\text { Tenericutes and } \\
\text { Euryarchaeota } \\
\text { Firmicutes } \\
\text { Lachnospiraceae }\end{array}$ \\
\hline $\begin{array}{l}\text { Tetz et al } \\
2018[61]\end{array}$ & 31 & 38 & $\begin{array}{l}\text { Shotgun } \\
\text { Sequencing }\end{array}$ & $\begin{array}{l}\text { Change bacteriopgahe } \\
\text { composition at the family } \\
\text { level: } \\
\text { Abundance of lytic } \\
\text { Lactococcus phages (shift in } \\
\text { neurotransmitter-producing } \\
\text { Lactococcus) }\end{array}$ & $\begin{array}{l}\text { Prevotellaceae } \\
\text { Lachnospiraceae } \\
\text { Lactobacillaceae } \\
\text { Streptococcaceae }\end{array}$ \\
\hline
\end{tabular}

Table 1. Existing studies on gut microbiota in PD. C: controls; as: amplicon sequencing; qPCR: quantitative PCR; +: bacteria more abundant in PD as compared to controls; -: bacteria less abundant in PD as compared to controls.

\begin{tabular}{|l|c|c|l|l|}
\hline \multicolumn{1}{|c|}{ Study } & PD & C & \multicolumn{1}{|c|}{ Technique } & \multicolumn{1}{c|}{ Results } \\
\hline Davies et al. 1996 [54] & 15 & 15 & In vivo UES & Increased L/M ratio in PD \\
\hline Forsyth et al. 2011 [56] & 9 & 10 & In vivo UES & $\begin{array}{l}\text { Increased sucralose excretion in PD } \\
\text { L/M ratio unchanged }\end{array}$ \\
\hline Salat-Foix et al. 2012 [55] & 12 & $0^{*}$ & In vivo UES & Increased L/M ratio in 2/12 PD \\
\hline Clairembault et al. 2015 [57] & 31 & 11 & Ex vivo Ussing & No differences between PD and C \\
\hline
\end{tabular}

Tableau 2. Existing studies on intestinal permeability in PD. UES: urinary excretion of sugars; C: controls; L/M ratio: lactulose/mannitol ratio. ${ }^{*}$ No control group, values were compared to standard references.

\section{References}

[1] L.L. Edwards, E.M. Quigley, R.F. Pfeiffer, Gastrointestinal dysfunction in Parkinson's disease: frequency and pathophysiology, Neurology. 42 (1992) 726-732.

[2] K. Wakabayashi, H. Takahashi, S. Takeda, E. Ohama, F. Ikuta, Parkinson's disease: the presence of Lewy bodies in Auerbach's and Meissner's plexuses, Acta Neuropathol. 76 (1988) 217-221.

[3] T.G. Beach, C.H. Adler, L.I. Sue, L. Vedders, L. Lue, C.L. White Iii, H. Akiyama, J.N. Caviness, H.A. Shill, M.N. Sabbagh, D.G. Walker, Arizona Parkinson's Disease 
Consortium, Multi-organ distribution of phosphorylated alpha-synuclein histopathology in subjects with Lewy body disorders, Acta Neuropathol. 119 (2010) 689-702. doi:10.1007/s00401-010-0664-3.

[4] E. Gelpi, J. Navarro-Otano, E. Tolosa, C. Gaig, Y. Compta, M.J. Rey, M.J. Martí, I. Hernández, F. Valldeoriola, R. Reñé, T. Ribalta, Multiple organ involvement by alphasynuclein pathology in Lewy body disorders, Mov. Disord. 29 (2014) 1010-1018. doi:10.1002/mds.25776.

[5] H. Braak, K. Del Tredici, U. Rüb, R.A.I. de Vos, E.N.H. Jansen Steur, E. Braak, Staging of brain pathology related to sporadic Parkinson's disease, Neurobiol. Aging. 24 (2003) 197-211.

[6] H. Braak, R.A.I. de Vos, J. Bohl, K. Del Tredici, Gastric alpha-synuclein immunoreactive inclusions in Meissner's and Auerbach's plexuses in cases staged for Parkinson's disease-related brain pathology, Neurosci. Lett. 396 (2006) 67-72. doi:10.1016/j.neulet.2005.11.012.

[7] P. Borghammer, How does parkinson's disease begin? Perspectives on neuroanatomical pathways, prions, and histology, Mov. Disord. 33 (2018) 48-57. doi:10.1002/mds.27138.

[8] A. Lionnet, L. Leclair-Visonneau, M. Neunlist, S. Murayama, M. Takao, C.H. Adler, P. Derkinderen, T.G. Beach, Does Parkinson's disease start in the gut?, Acta Neuropathol. 135 (2018) 1-12. doi:10.1007/s00401-017-1777-8.

[9] N. Sudo, Y. Chida, Y. Aiba, J. Sonoda, N. Oyama, X.-N. Yu, C. Kubo, Y. Koga, Postnatal microbial colonization programs the hypothalamic-pituitary-adrenal system for stress response in mice, J. Physiol. (Lond.). 558 (2004) 263-275.

doi:10.1113/jphysiol.2004.063388.

[10] L.K. McCorry, Physiology of the autonomic nervous system, Am J Pharm Educ. 71 (2007) 78 .

[11] M.P. Lilly, D.S. Gann, The hypothalamic-pituitary-adrenal-immune axis. A critical assessment, Arch Surg. 127 (1992) 1463-1474.

[12] M. Schemann, M. Neunlist, The human enteric nervous system, Neurogastroenterol. Motil. 16 Suppl 1 (2004) 55-59. doi:10.1111/j.1743-3150.2004.00476.x.

[13] K.R. Jessen, R. Mirsky, Astrocyte-like glia in the peripheral nervous system: an immunohistochemical study of enteric glia, J. Neurosci. 3 (1983) 2206-2218.

[14] F.M. Gribble, F. Reimann, Enteroendocrine Cells: Chemosensors in the Intestinal Epithelium, Annu. Rev. Physiol. 78 (2016) 277-299. doi:10.1146/annurev-physiol-021115105439.

[15] A.M. Marchiando, W.V. Graham, J.R. Turner, Epithelial barriers in homeostasis and disease, Annu Rev Pathol. 5 (2010) 119-144. doi:10.1146/annurev.pathol.4.110807.092135.

[16] T. Suzuki, Regulation of intestinal epithelial permeability by tight junctions, Cell. Mol. Life Sci. 70 (2013) 631-659. doi:10.1007/s00018-012-1070-x.

[17] Y. Bhattarai, Microbiota-gut-brain axis: Interaction of gut microbes and their metabolites with host epithelial barriers, Neurogastroenterol. Motil. 30 (2018) e13366. doi:10.1111/nmo.13366.

[18] L. Michel, A. Prat, One more role for the gut: microbiota and blood brain barrier, Ann Transl Med. 4 (2016) 15. doi:10.3978/j.issn.2305-5839.2015.10.16.

[19] D. Erny, A.L. Hrabě de Angelis, D. Jaitin, P. Wieghofer, O. Staszewski, E. David, H. Keren-Shaul, T. Mahlakoiv, K. Jakobshagen, T. Buch, V. Schwierzeck, O. Utermöhlen, E. Chun, W.S. Garrett, K.D. McCoy, A. Diefenbach, P. Staeheli, B. Stecher, I. Amit, M. Prinz, Host microbiota constantly control maturation and function of microglia in the CNS, Nat. Neurosci. 18 (2015) 965-977. doi:10.1038/nn.4030.

[20] F. Scheperjans, V. Aho, P.A.B. Pereira, K. Koskinen, L. Paulin, E. Pekkonen, E. 
Haapaniemi, S. Kaakkola, J. Eerola-Rautio, M. Pohja, E. Kinnunen, K. Murros, P. Auvinen, Gut microbiota are related to Parkinson's disease and clinical phenotype, Mov. Disord. 30 (2015) 350-358. doi:10.1002/mds.26069.

[21] A. Keshavarzian, S.J. Green, P.A. Engen, R.M. Voigt, A. Naqib, C.B. Forsyth, E. Mutlu, K.M. Shannon, Colonic bacterial composition in Parkinson's disease, Mov. Disord. 30 (2015) 1351-1360. doi:10.1002/mds.26307.

[22] M.M. Unger, J. Spiegel, K.-U. Dillmann, D. Grundmann, H. Philippeit, J. Bürmann, K. Faßbender, A. Schwiertz, K.-H. Schäfer, Short chain fatty acids and gut microbiota differ between patients with Parkinson's disease and age-matched controls, Parkinsonism Relat. Disord. 32 (2016) 66-72. doi:10.1016/j.parkreldis.2016.08.019.

[23] J.R. Bedarf, F. Hildebrand, L.P. Coelho, S. Sunagawa, M. Bahram, F. Goeser, P. Bork, U. Wüllner, Functional implications of microbial and viral gut metagenome changes in early stage L-DOPA-naïve Parkinson's disease patients, Genome Med. 9 (2017) 39. doi:10.1186/s13073-017-0428-y.

[24] E.M. Hill-Burns, J.W. Debelius, J.T. Morton, W.T. Wissemann, M.R. Lewis, Z.D. Wallen, S.D. Peddada, S.A. Factor, E. Molho, C.P. Zabetian, R. Knight, H. Payami, Parkinson's disease and Parkinson's disease medications have distinct signatures of the gut microbiome, Mov. Disord. 32 (2017) 739-749. doi:10.1002/mds.26942.

[25] A. Heintz-Buschart, U. Pandey, T. Wicke, F. Sixel-Döring, A. Janzen, E. SittigWiegand, C. Trenkwalder, W.H. Oertel, B. Mollenhauer, P. Wilmes, The nasal and gut microbiome in Parkinson's disease and idiopathic rapid eye movement sleep behavior disorder, Mov. Disord. 33 (2018) 88-98. doi:10.1002/mds.27105.

[26] S. Hasegawa, S. Goto, H. Tsuji, T. Okuno, T. Asahara, K. Nomoto, A. Shibata, Y. Fujisawa, T. Minato, A. Okamoto, K. Ohno, M. Hirayama, Intestinal Dysbiosis and Lowered Serum Lipopolysaccharide-Binding Protein in Parkinson's Disease, PLoS ONE. 10 (2015) e0142164. doi:10.1371/journal.pone.0142164.

[27] V.A. Petrov, I.V. Saltykova, I.A. Zhukova, V.M. Alifirova, N.G. Zhukova, Y.B. Dorofeeva, A.V. Tyakht, B.A. Kovarsky, D.G. Alekseev, E.S. Kostryukova, Y.S. Mironova, O.P. Izhboldina, M.A. Nikitina, T.V. Perevozchikova, E.A. Fait, V.V. Babenko, M.T. Vakhitova, V.M. Govorun, A.E. Sazonov, Analysis of Gut Microbiota in Patients with Parkinson's Disease, Bull. Exp. Biol. Med. 162 (2017) 734-737. doi:10.1007/s10517-0173700-7.

[28] F. Hopfner, A. Künstner, S.H. Müller, S. Künzel, K.E. Zeuner, N.G. Margraf, G. Deuschl, J.F. Baines, G. Kuhlenbäumer, Gut microbiota in Parkinson disease in a northern German cohort, Brain Res. 1667 (2017) 41-45. doi:10.1016/j.brainres.2017.04.019.

[29] W. Li, X. Wu, X. Hu, T. Wang, S. Liang, Y. Duan, F. Jin, B. Qin, Structural changes of gut microbiota in Parkinson's disease and its correlation with clinical features, Sci China Life Sci. 60 (2017) 1223-1233. doi:10.1007/s11427-016-9001-4.

[30] Y. Qian, X. Yang, S. Xu, C. Wu, Y. Song, N. Qin, S.-D. Chen, Q. Xiao, Alteration of the fecal microbiota in Chinese patients with Parkinson's disease, Brain Behav. Immun. 70 (2018) 194-202. doi:10.1016/j.bbi.2018.02.016.

[31] T.R. Sampson, J.W. Debelius, T. Thron, S. Janssen, G.G. Shastri, Z.E. Ilhan, C. Challis, C.E. Schretter, S. Rocha, V. Gradinaru, M.-F. Chesselet, A. Keshavarzian, K.M. Shannon, R. Krajmalnik-Brown, P. Wittung-Stafshede, R. Knight, S.K. Mazmanian, Gut Microbiota Regulate Motor Deficits and Neuroinflammation in a Model of Parkinson's Disease, Cell. 167 (2016) 1469-1480.e12. doi:10.1016/j.cell.2016.11.018.

[32] J.G. Choi, N. Kim, I.G. Ju, H. Eo, S.-M. Lim, S.-E. Jang, D.-H. Kim, M.S. Oh, Oral administration of Proteus mirabilis damages dopaminergic neurons and motor functions in mice, Sci Rep. 8 (2018) 1275. doi:10.1038/s41598-018-19646-X.

[33] M. Bialecka, M. Kurzawski, G. Klodowska-Duda, G. Opala, S. Juzwiak, G. 
Kurzawski, E.-K. Tan, M. Drozdzik, CARD15 variants in patients with sporadic Parkinson's disease, Neurosci. Res. 57 (2007) 473-476. doi:10.1016/j.neures.2006.11.012.

[34] J.Z. Liu, S. van Sommeren, H. Huang, S.C. Ng, R. Alberts, A. Takahashi, S. Ripke, J.C. Lee, L. Jostins, T. Shah, S. Abedian, J.H. Cheon, J. Cho, N.E. Dayani, L. Franke, Y.

Fuyuno, A. Hart, R.C. Juyal, G. Juyal, W.H. Kim, A.P. Morris, H. Poustchi, W.G. Newman, V. Midha, T.R. Orchard, H. Vahedi, A. Sood, J.Y. Sung, R. Malekzadeh, H.-J. Westra, K. Yamazaki, S.-K. Yang, International Multiple Sclerosis Genetics Consortium, International IBD Genetics Consortium, J.C. Barrett, B.Z. Alizadeh, M. Parkes, T. Bk, M.J. Daly, M.

Kubo, C.A. Anderson, R.K. Weersma, Association analyses identify 38 susceptibility loci for inflammatory bowel disease and highlight shared genetic risk across populations, Nat. Genet. 47 (2015) 979-986. doi:10.1038/ng.3359.

[35] K.Y. Hui, H. Fernandez-Hernandez, J. Hu, A. Schaffner, N. Pankratz, N.-Y. Hsu, L.-S. Chuang, S. Carmi, N. Villaverde, X. Li, M. Rivas, A.P. Levine, X. Bao, P.R. Labrias, T. Haritunians, D. Ruane, K. Gettler, E. Chen, D. Li, E.R. Schiff, N. Pontikos, N. Barzilai, S.R. Brant, S. Bressman, A.S. Cheifetz, L.N. Clark, M.J. Daly, R.J. Desnick, R.H. Duerr, S. Katz, T. Lencz, R.H. Myers, H. Ostrer, L. Ozelius, H. Payami, Y. Peter, J.D. Rioux, A.W. Segal, W.K. Scott, M.S. Silverberg, J.M. Vance, I. Ubarretxena-Belandia, T. Foroud, G. Atzmon, I. Pe'er, Y. Ioannou, D.P.B. McGovern, Z. Yue, E.E. Schadt, J.H. Cho, I. Peter, Functional variants in the LRRK2 gene confer shared effects on risk for Crohn's disease and Parkinson's disease, Sci Transl Med. 10 (2018). doi:10.1126/scitranslmed.aai7795.

[36] M. Villumsen, S. Aznar, B. Pakkenberg, T. Jess, T. Brudek, Inflammatory bowel disease increases the risk of Parkinson's disease: a Danish nationwide cohort study 19772014, Gut. (2018). doi:10.1136/gutjnl-2017-315666.

[37] I. Peter, M. Dubinsky, S. Bressman, A. Park, C. Lu, N. Chen, A. Wang, Anti-Tumor Necrosis Factor Therapy and Incidence of Parkinson Disease Among Patients With Inflammatory Bowel Disease, JAMA Neurol. (2018). doi:10.1001/jamaneurol.2018.0605.

[38] S.-W. Lai, K.-F. Liao, C.-L. Lin, F.-C. Sung, Irritable bowel syndrome correlates with increased risk of Parkinson's disease in Taiwan, Eur. J. Epidemiol. 29 (2014) 57-62. doi:10.1007/s10654-014-9878-3.

[39] T.H. Mertsalmi, V.T.E. Aho, P. a. B. Pereira, L. Paulin, E. Pekkonen, P. Auvinen, F. Scheperjans, More than constipation - bowel symptoms in Parkinson's disease and their connection to gut microbiota, Eur. J. Neurol. 24 (2017) 1375-1383. doi:10.1111/ene.13398.

[40] D. Devos, T. Lebouvier, B. Lardeux, M. Biraud, T. Rouaud, H. Pouclet, E. Coron, S. Bruley des Varannes, P. Naveilhan, J.-M. Nguyen, M. Neunlist, P. Derkinderen, Colonic inflammation in Parkinson's disease, Neurobiol. Dis. 50 (2013) 42-48.

doi:10.1016/j.nbd.2012.09.007.

[41] A. Rühl, S. Franzke, S.M. Collins, W. Stremmel, Interleukin-6 expression and regulation in rat enteric glial cells, Am. J. Physiol. Gastrointest. Liver Physiol. 280 (2001) G1163-1171. doi:10.1152/ajpgi.2001.280.6.G1163.

[42] T. Clairembault, W. Kamphuis, L. Leclair-Visonneau, M. Rolli-Derkinderen, E. Coron, M. Neunlist, E.M. Hol, P. Derkinderen, Enteric GFAP expression and phosphorylation in Parkinson's disease, J. Neurochem. 130 (2014) 805-815. doi:10.1111/jnc. 12742.

[43] C. Pellegrini, M. Fornai, R. Colucci, E. Tirotta, F. Blandini, G. Levandis, S. Cerri, C. Segnani, C. Ippolito, N. Bernardini, K. Cseri, C. Blandizzi, G. Haskó, L. Antonioli, Alteration of colonic excitatory tachykininergic motility and enteric inflammation following dopaminergic nigrostriatal neurodegeneration, J Neuroinflammation. 13 (2016) 146. doi:10.1186/s12974-016-0608-5.

[44] P. Teismann, K. Tieu, D.-K. Choi, D.-C. Wu, A. Naini, S. Hunot, M. Vila, V. JacksonLewis, S. Przedborski, Cyclooxygenase-2 is instrumental in Parkinson's disease neurodegeneration, Proc. Natl. Acad. Sci. U.S.A. 100 (2003) 5473-5478. 
doi:10.1073/pnas.0837397100.

[45] C. Pochard, L. Leclair-Visonneau, E. Coron, M. Neunlist, M. Rolli-Derkinderen, P. Derkinderen, Cyclooxygenase 2 is upregulated in the gastrointestinal tract in Parkinson's disease, Mov. Disord. 33 (2018) 493-494. doi:10.1002/mds.27237.

[46] M.C. Houser, J. Chang, S.A. Factor, E.S. Molho, C.P. Zabetian, E.M. Hill-Burns, H. Payami, V.S. Hertzberg, M.G. Tansey, Stool Immune Profiles Evince Gastrointestinal Inflammation in Parkinson's Disease, Mov. Disord. 33 (2018) 793-804. doi:10.1002/mds. 27326.

[47] A. Schwiertz, J. Spiegel, U. Dillmann, D. Grundmann, J. Bürmann, K. Faßbender, K.H. Schäfer, M.M. Unger, Fecal markers of intestinal inflammation and intestinal permeability are elevated in Parkinson's disease, Parkinsonism Relat. Disord. 50 (2018) 104-107. doi:10.1016/j.parkreldis.2018.02.022.

[48] E.C. Hirsch, S. Vyas, S. Hunot, Neuroinflammation in Parkinson's disease, Parkinsonism Relat. Disord. 18 Suppl 1 (2012) S210-212. doi:10.1016/S13538020(11)70065-7.

[49] A. Gerhard, N. Pavese, G. Hotton, F. Turkheimer, M. Es, A. Hammers, K. Eggert, W. Oertel, R.B. Banati, D.J. Brooks, In vivo imaging of microglial activation with [11C](R)PK11195 PET in idiopathic Parkinson's disease, Neurobiol. Dis. 21 (2006) 404-412. doi:10.1016/j.nbd.2005.08.002.

[50] M.G. Stokholm, A. Iranzo, K. Østergaard, M. Serradell, M. Otto, K.B. Svendsen, A. Garrido, D. Vilas, P. Borghammer, J. Santamaria, A. Møller, C. Gaig, D.J. Brooks, E. Tolosa, N. Pavese, Assessment of neuroinflammation in patients with idiopathic rapid-eye-movement sleep behaviour disorder: a case-control study, Lancet Neurol. 16 (2017) 789-796.

doi:10.1016/S1474-4422(17)30173-4.

[51] T. Piche, G. Barbara, P. Aubert, S. Bruley des Varannes, R. Dainese, J.L. Nano, C. Cremon, V. Stanghellini, R. De Giorgio, J.P. Galmiche, M. Neunlist, Impaired intestinal barrier integrity in the colon of patients with irritable bowel syndrome: involvement of soluble mediators, Gut. 58 (2009) 196-201. doi:10.1136/gut.2007.140806.

[52] K.D. Katz, D. Hollander, C.M. Vadheim, C. McElree, T. Delahunty, V.D. Dadufalza, P. Krugliak, J.I. Rotter, Intestinal permeability in patients with Crohn's disease and their healthy relatives, Gastroenterology. 97 (1989) 927-931.

[53] D. Hollander, Intestinal permeability, leaky gut, and intestinal disorders, Curr Gastroenterol Rep. 1 (1999) 410-416.

[54] K.N. Davies, D. King, D. Billington, J.A. Barrett, Intestinal permeability and orocaecal transit time in elderly patients with Parkinson's disease, Postgrad Med J. 72 (1996) 164-167.

[55] D. Salat-Foix, K. Tran, R. Ranawaya, J. Meddings, O. Suchowersky, Increased intestinal permeability and Parkinson disease patients: chicken or egg?, Can J Neurol Sci. 39 (2012) 185-188.

[56] C.B. Forsyth, K.M. Shannon, J.H. Kordower, R.M. Voigt, M. Shaikh, J.A. Jaglin, J.D. Estes, H.B. Dodiya, A. Keshavarzian, Increased intestinal permeability correlates with sigmoid mucosa alpha-synuclein staining and endotoxin exposure markers in early Parkinson's disease, PLoS ONE. 6 (2011) e28032. doi:10.1371/journal.pone.0028032. [57] T. Clairembault, L. Leclair-Visonneau, E. Coron, A. Bourreille, S. Le Dily, F. Vavasseur, M.-F. Heymann, M. Neunlist, P. Derkinderen, Structural alterations of the intestinal epithelial barrier in Parkinson's disease, Acta Neuropathol Commun. 3 (2015) 12. doi:10.1186/s40478-015-0196-0.

[58] D.V. Bohórquez, L.A. Samsa, A. Roholt, S. Medicetty, R. Chandra, R.A. Liddle, An enteroendocrine cell-enteric glia connection revealed by 3D electron microscopy, PLoS ONE. 9 (2014) e89881. doi:10.1371/journal.pone.0089881. 
[59] R. Chandra, A. Hiniker, Y.-M. Kuo, R.L. Nussbaum, R.A. Liddle, $\alpha$-Synuclein in gut endocrine cells and its implications for Parkinson's disease, JCI Insight. 2 (2017). doi:10.1172/jci.insight.92295.

[60] A. Lin, W. Zheng, Y. He, W. Tang, X. Wei, R. He, W. Huang, Y. Su, Y. Huang, H. Zhou, H. Xie, Gut microbiota in patients with Parkinson's disease in southern China, Parkinsonism Relat. Disord. 53 (2018) 82-88. doi:10.1016/j.parkreldis.2018.05.007.

[61] G. Tetz, S.M. Brown, Y. Hao, V. Tetz, Parkinson's disease and bacteriophages as its overlooked contributors, Sci Rep. 8 (2018) 10812. doi:10.1038/s41598-018-29173-4. 
Figure 1

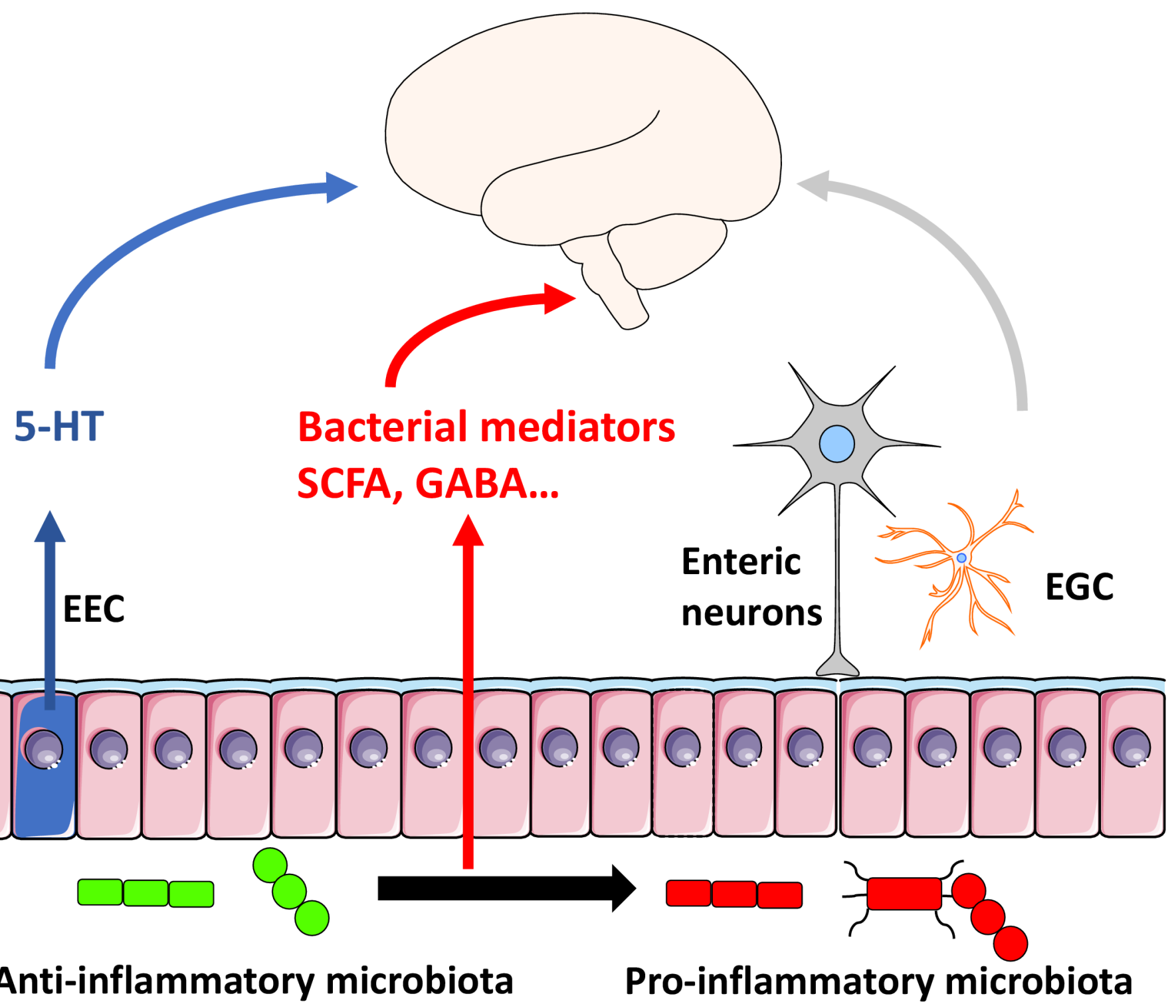


Figure 2

A

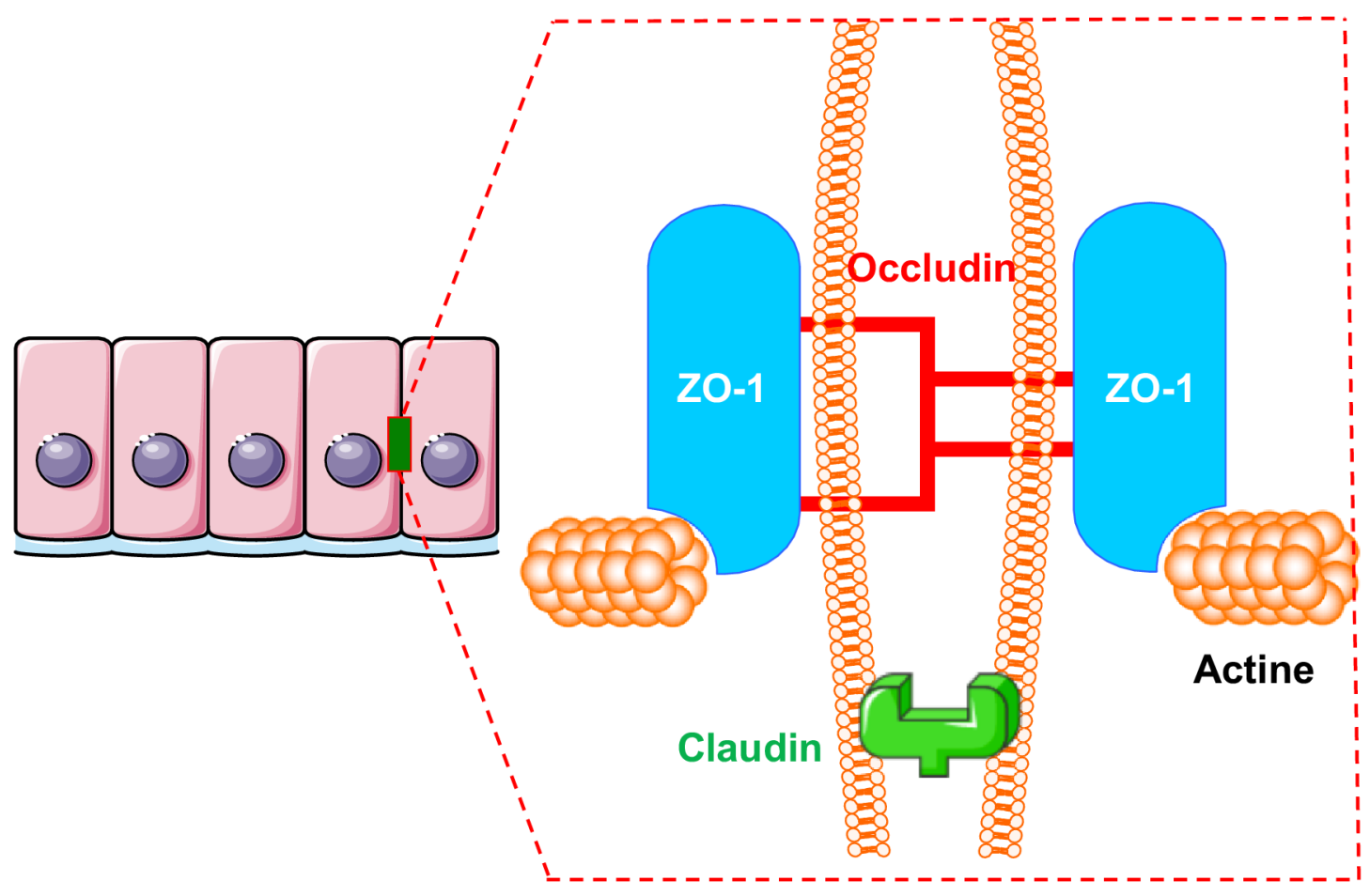

B
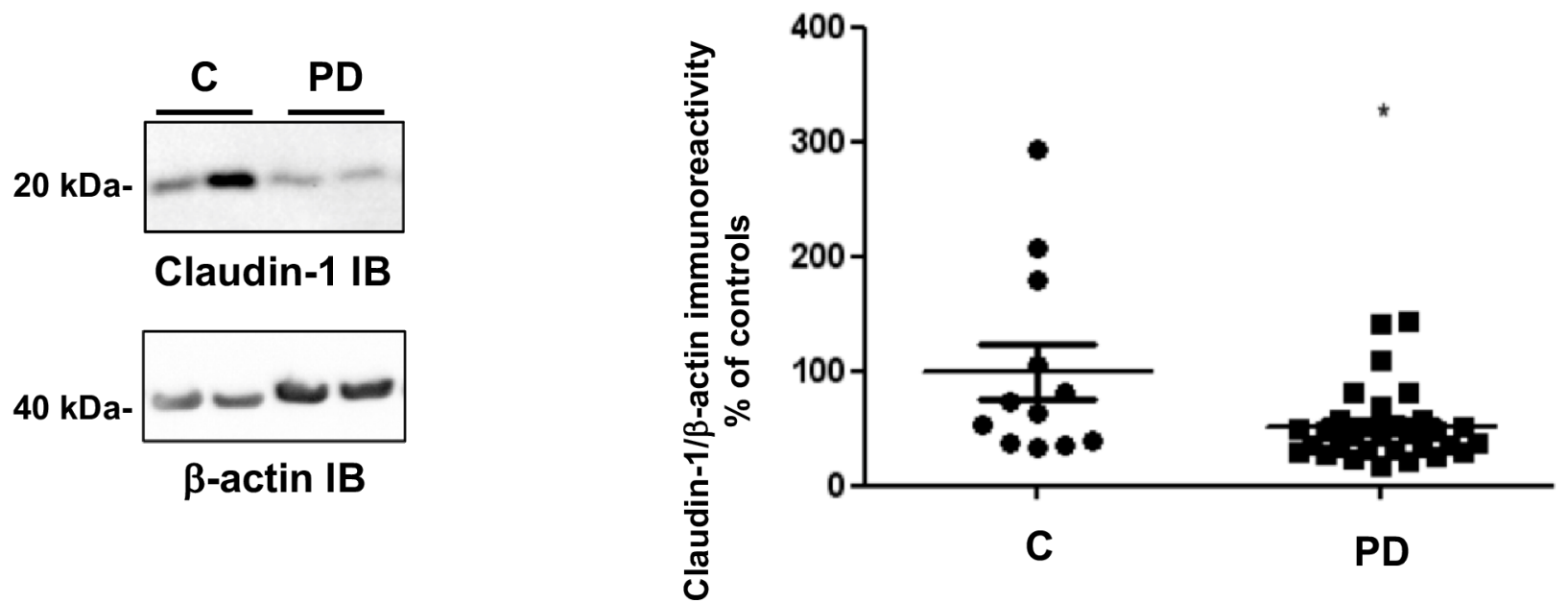